
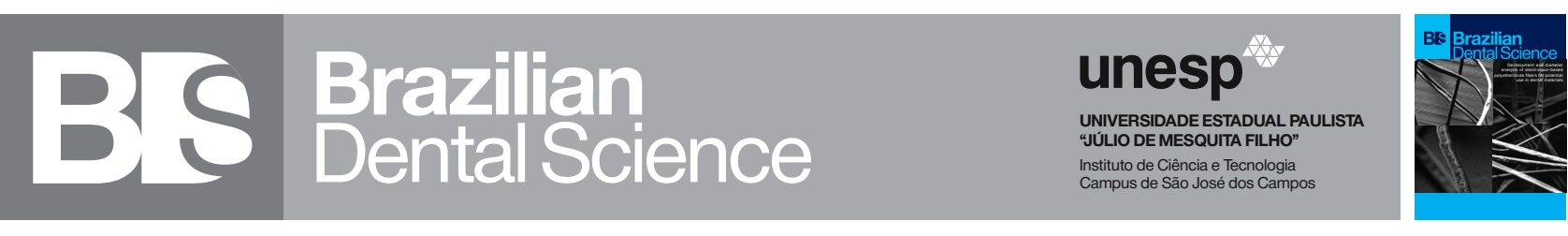

\title{
Effects of salbutamol, montelukast and prednisone on orthodontic tooth movement in rats
}

\author{
Efeitos do salbutamol, montelucaste e prednisona no movimento dentário ortodôntico em ratos \\ Victor CHUMPITAZ-CERRATE ${ }^{1,2}$, Lesly CHÁVEZ-RIMACHE ${ }^{1}$, César FRANCO-QUINO ${ }^{1,2}$, Eliberto RUIZ-RAMIREZ ${ }^{1,2}$, Elías AGUIRRE- \\ SIANCAS ${ }^{1}$, Carlos ERAZO-PAREDES ${ }^{1}$ \\ 1 - Grupo de Investigación en Ciencias Básicas Estomatológicas, Universidad Nacional Mayor de San Marcos, Lima, Perú. \\ 2 - Laboratorio de Farmacología, Universidad Científica del Sur, Lima, Perú.
}

\section{ABSTRACT}

Objective: To evaluate the effect of salbutamol, montelukast, and prednisone on orthodontic tooth movement in rats. Material and Methods: In vivo experimental preclinical study. The sample consisted of 48 rats randomly distributed in four study groups. Group A was given saline solution; to group B, salbutamol $4 \mathrm{mg} / \mathrm{Kg}$; to group C, montelukast 2.5 $\mathrm{mg} / \mathrm{Kg}$ and to group D, prednisone $2.5 \mathrm{mg} / \mathrm{Kg}$. All were fitted with orthodontic devices and the medications were administered intraperitoneally every 12 hours for 5 days. The clinical evaluation (variation in the interincisal distance) was performed at one, three, five, and seven days and the histopathological analysis (cell count) at five and seven days. Results: In the clinical evaluation of the variation in the interincisal distance, a significant difference was found in all the evaluations ( $\mathrm{p}<0.05)$. It was found that the salbutamol group presented higher variation values in the interincisal distance on all the days evaluated. In the histopathological analysis at five and seven days, it was found that the osteoblast and osteocyte count was significantly higher in the salbutamol group compared to the other groups $(\mathrm{p}<0.05)$. However, in the subgroup analysis, it was found that there was no significant difference in the osteoblast and osteocyte count between the prednisone, montelukast, and control group ( $p>0.05$ ). Conclusion: The administration of salbutamol increased the magnitude of orthodontic tooth movement; nonetheless, the administration of montelukast and prednisone did not modify the magnitude of orthodontic tooth movement in rats.

\section{KEYWORDS}

Albuterol; Montelukast; Prednisone; Rats; Tooth movement.

\section{RESUMO}

Objetivo: Avaliar o efeito do salbutamol, montelucaste e prednisona no movimento dentário ortodôntico em ratos. Material e métodos: Estudo pré-clínico experimental in vivo. A amostra foi composta por 48 ratos distribuídos aleatoriamente em quatro grupos de estudo. O grupo A recebeu solução salina; para o grupo B, salbutamol $4 \mathrm{mg} / \mathrm{kg}$; ao grupo C, montelucaste $2,5 \mathrm{mg} / \mathrm{kg}$ e ao grupo D, prednisona $2,5 \mathrm{mg} / \mathrm{kg}$. Todos foram equipados com dispositivos ortodônticos e os medicamentos foram administrados por via intraperitoneal a cada 12 horas por 5 dias. A avaliação clínica (variação da distância interincisal) foi realizada em um, três, cinco e sete dias e a análise histopatológica (contagem de células) em cinco e sete dias. Resultados: Na avaliação clínica da variação da distância interincisal, houve diferença significativa em todas as avaliações $(\mathrm{p}<0,05)$. Verificou-se que o grupo salbutamol apresentou maiores valores de variação na distância interincisal em todos os dias avaliados. Na análise histopatológica aos cinco e sete dias, verificou-se que a contagem de osteoblastos e osteócitos foi significativamente maior no grupo salbutamol em comparação aos demais grupos $(\mathrm{p}<0,05)$. No entanto, na análise de subgrupos, verificou-se que não houve diferença significativa na contagem de osteoblastos e osteócitos entre os grupos prednisona, montelucaste e controle $(p>0,05)$. Conclusão: A administração de salbutamol aumentou a magnitude do movimento dentário ortodôntico; no entanto, a administração de montelucaste e prednisona não modificou a magnitude do movimento dos dentes ortodônticos em ratos.

\section{PALAVRAS-CHAVE}

Albuterol; Montelucaste; Prednisona; Ratos; Movimento dentário. 


\section{INTRODUCTION}

$\mathrm{T} \mathrm{n}$ recent years, the number of patients 1 requiring orthodontic treatment has increased, some of them with systemic diseases that need medication [1]. Asthma is a chronic disease that affects around 300 million people worldwide, mainly to pediatric patients [2,3]. Among the drugs used for its treatment are beta- 2 agonists (salbutamol, formoterol), corticosteroids (beclomethasone, prednisone) and leukotriene receptor antagonists (zafirlukast, montelukast) [4]. Pharmacotherapy of asthma includes drugs that could affect orthodontic tooth movement [5]. Therefore, it is important to determine what is the role of these drugs to carry out treatment planning considering the possible changes that could occur due to the patient's condition.

Orthodontic tooth movement (OTM) can vary depending on the applied forces, size, and response of the periodontal ligament [68]. Some studies report that the adrenergic system can regulate bone remodeling through beta- 2 receptors, inhibiting bone formation and increasing osteoclastogenesis in cell cultures $[9,10]$. In vitro studies have reported that leukotrienes can decrease osteoblast proliferation and activity while stimulating osteoclast formation and activity [11]. These findings suggest that antileukotrienes could modify bone remodeling.

On corticosteroids, Nie et al. [12] reported that methylprednisolone causes apoptosis of osteoblasts in rat femur and dexamethasone decreases osteoblast viability in cell culture; however, other clinical experimental studies in animals and cell cultures report that the effect of corticosteroids on bone remodeling is variable, depending on the induction period and the dose administered $[4,13,14]$.

Consequently, considering the high prevalence of asthma, the controversies about the variability of the effect of anti-asthmatic drugs on OTM and that this preclinical study in vivo can lead to clinical studies that allow decisions to be made for planning and monitoring after Orthodontic treatment, the objective of the present investigation was to evaluate the effect of salbutamol, montelukast and prednisone on orthodontic tooth movement in rats.

\section{MATERIAL AND METHODS}

\section{Ethical considerations}

The recommendations of the ARRIVE guidelines (Animal Research: Reporting of In Vivo Experiments) were considered [15]. In addition to that recommended by the guideline of the National Institutes of Health for the care and use of laboratory animals [16]. In vivo experimental preclinical study was approved by the research institute of the Faculty of Dentistry of the Universidad Nacional Mayor de San Marcos. The sample consisted of 48 male Wistar rats, 8 weeks old, weighing between 200 and $250 \mathrm{~g}$. The rats were conditioned and set for 7 days with ventilation of $20 \pm 5{ }^{\circ} \mathrm{C}$, ad libitum feeding with humidity of $40 \%$ to $50 \%$ and with light/dark cycles of 12 hours in the Bioterio of the Faculty of Medicine of the National University of San Marcos.

All rats were randomly assigned to four groups (A, B C, and D). Group A (control) was administered $9 \mathrm{mg} / \mathrm{kg}$ saline; to group $\mathrm{B}$, salbutamol $4 \mathrm{mg} / \mathrm{Kg}$; to group C, montelukast 2.5 $\mathrm{mg} / \mathrm{Kg}$ and to group D, prednisone $2.5 \mathrm{mg} / \mathrm{Kg}$. All treatments were administered intraperitoneally every 12 hours for five days.

Treatment protocol and placement of the orthodontic device

The appliance was constructed based on the models made by Novaes et al. [17], Gonçalves et al. [18] and Magdalen et al. [19]. The orthodontic device was made with 0.016 inch beta-titanium wire. An independent anchorage was made to fix it to each right and left incisor tooth, then the device was adapted to the palate with a threeturn wire bend with a diameter of $2 \mathrm{~mm}$ and with a symmetrical extension of the arms of $10 \mathrm{~mm}$. The orthodontic device was activated with a force of $35 \mathrm{~g}$, which was regulated with a dynamometer (Figure 1A).

All 48 rats were anesthetized with pentobarbital (Halatal ${ }^{\circledR}$ ) at a dose of $1 \mathrm{mg} / 2.5 \mathrm{Kg}$ intraperitoneally. Subsequently, the baseline measurement of the distance between the incisional angles of the maxillary incisors of all rats was carried out, using a precision caliper of $0.01 \mathrm{~mm}$ (Mitutoyo ${ }^{\circledR}$, Japon). Then, with a fissure diamond bur $(0.5 \mathrm{~mm})$, a wear was made on the mesial surface of the maxillary incisors, 
to allow the placement of the orthodontic device. Subsequently, acid etching with $37 \%$ O-phosphoric acid was performed for 30 seconds in the gingival third of the vestibular surface. The arms of the orthodontic device passed from palatal to vestibular and were fixed in the gingival third of the vestibular surface with lightcuring resin (Transbond XT, $3 \mathrm{M}^{\circledR}$, United States) for seven days (Figures 1B, 1C and 1D).

OTM was evaluated by clinical evaluation and histopathological analysis.

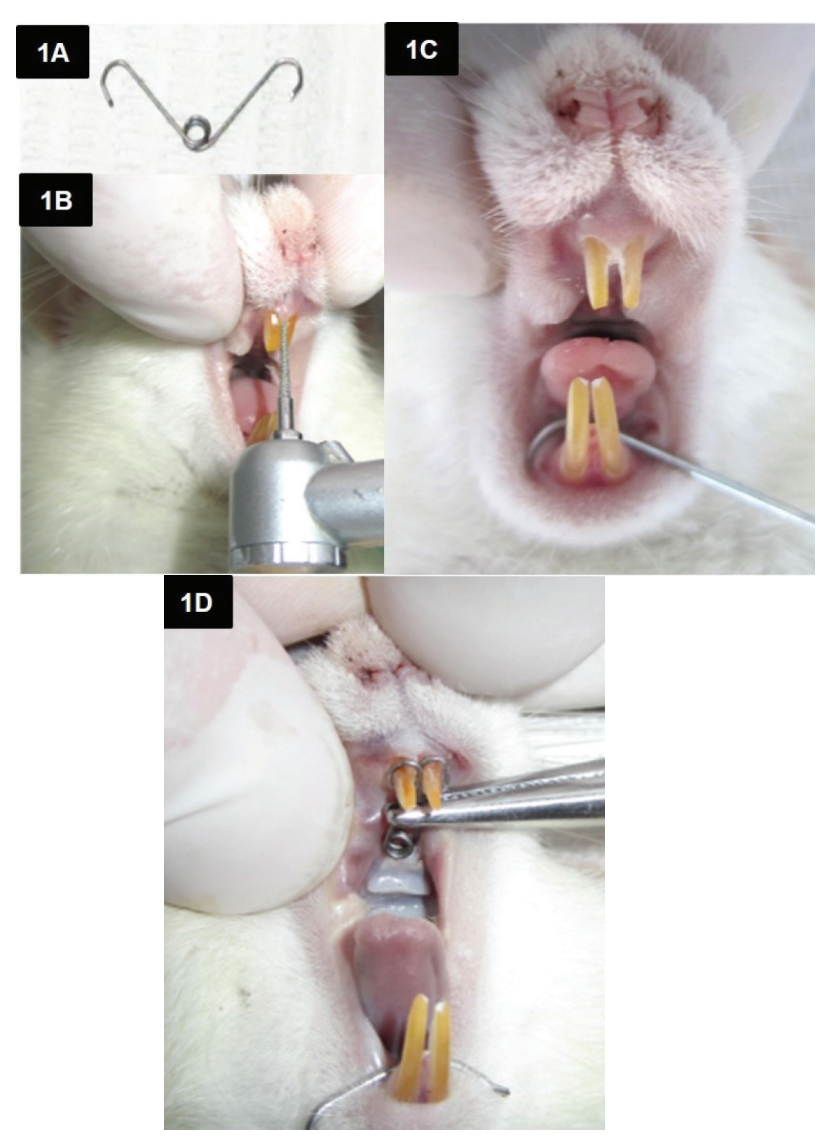

Figure 1- Sequence of orthodontic device placement in Wistar rats. 1A. Orthodontic appliance made of 0.016 inch betatitanium wire. 1B. Wear on the mesial surface of the maxillary incisors with a $0.5 \mathrm{~mm}$ fissure bur. 1C. Front view of the maxillary incisors after the wear done. 1D. Placement of the orthodontic device in the interproximal space of the maxillary incisors and fixed in the cervical third of the vestibular surface.

\section{Clinical evaluation}

The distance between the incisodistal angles of the maxillary incisors was measured on day one, three, five, and seven days after the placement of the orthodontic device. The value of the variation in the interincisal distance was determined using the difference of the value obtained in each measurement minus the basal value. All measurements were made during the morning (9:00 am) by two independent researchers. Each investigator registered the average of three measurements.

\section{Histopathological analysis}

Six rats from each group were randomly selected at five and seven days, which were euthanized by an intraperitoneal $1 \mathrm{~mL} / 250 \mathrm{~g}$ pentobarbital overdose (HALATAL ${ }^{\circledR}$ ). Subsequently, samples were taken from the maxilla for the cell count.

After processing the samples, hematoxylin and eosin staining was performed. Digital images were taken using a light microscope (MCX100 LCD Crocus II, Micros ${ }^{\circledR}$, Germany). An analysis of the cell count was carried out by a pathologist, observing four random fields focusing on the interradicular bone of the maxillary incisors, and then the cell count of osteoblasts and osteocytes was performed on an hourly basis. An average of the four observations was taken. Each observed microscopic area was $0.458 \mathrm{~mm}^{2}$ with a total magnification of 400x.

\section{Statistical analysis}

Data was analyzed using the ANOVA and Kruskal-Wallis, then the post hoc analysis was performed using the Bonferroni and DunnBonferroni tests, respectively. The analyzes were performed considering a significance level of $5 \%$, using the STATA statistical package (Version SE 15.1).

\section{RESULTS}

\section{Clinical evaluation (variation in interincisal distance)}

In the determination of the variation in the interincisal distance (VIID) of all the study groups, a significant difference was found during all the evaluations $(\mathrm{p}<0.05)$.

In the post hoc analysis, significantly lower VIID values were found in the prednisone group at day one and significantly higher VIID values in the salbutamol group at three, five, and seven days compared to the control group $(\mathrm{p}<0.05)$ (Tables I and II). 
Table I - Variation in Interincisal Distance $(\mathrm{mm})$ according to treatment groups on days one and three

\begin{tabular}{|c|c|c|c|c|c|c|}
\hline \multirow{2}{*}{ GROUP } & \multicolumn{3}{|c|}{ DAY ONE } & \multicolumn{3}{|c|}{ DAY THREE } \\
\hline & $X \pm S D$ & IC 95\% & $\mathbf{p} \varphi$ & $X \pm S D$ & IC 95\% & $\mathbf{p} \varphi$ \\
\hline CONTROL & $1.13 \pm 0.15$ & $1.03-1.23$ & $<0.001$ & $1.33 \pm 0.13^{b}$ & $1.25-1.42$ & 0.001 \\
\hline SALBUTAMOL & $1.28 \pm 0.16$ & $1.18-1.38$ & & $1.63 \pm 0.19^{a}$ & $1.51-1.74$ & \\
\hline MONTELUKAST & $1.02 \pm 0.17^{b}$ & $0.91-1.13$ & & $1.26 \pm 0.14^{b}$ & $1.17-1.34$ & \\
\hline PREDNISONE & $0.24 \pm 0.10$ a & $0.18-0.31$ & & $1.32 \pm 0.28^{b}$ & $1.14-1.50$ & \\
\hline
\end{tabular}

$X \pm$ SD: Mean and Standard Deviation; $\varphi$ : Kruskal-Wallis test ( $p<0.05)$. a: Dunn-Bonferroni test ( $p<0.05$ with reference to the control group); b: Dunn-Bonferroni test ( $p<0.05$ with reference to the salbutamol group)

Table II - Variation in the Interincisal Distance $(\mathrm{mm})$ according to treatment groups on days five and seven

\begin{tabular}{|c|c|c|c|c|c|c|}
\hline \multirow{2}{*}{ GROUP } & \multicolumn{3}{|c|}{ DAY FIVE } & \multicolumn{3}{|c|}{ DAY SEVEN } \\
\hline & $X \pm S D$ & IC 95\% & $\mathbf{p} \varphi$ & $X \pm S D$ & IC 95\% & $\mathbf{p}^{\varphi}$ \\
\hline CONTROL & $1.56 \pm 0.14^{b}$ & $1.58-1.65$ & 0.001 & $1.73 \pm 0.11^{b}$ & $1.62-1.85$ & 0.002 \\
\hline SALBUTAMOL & $1.89 \pm 0.22^{\mathrm{a}}$ & $1.75-2.03$ & & $2.16 \pm 0.22^{a}$ & $1.93-2.40$ & \\
\hline MONTELUKAST & $1.51 \pm 0.09^{b}$ & $1.45-1.56$ & & $1.72 \pm 0.10^{b}$ & $1.62-1.82$ & \\
\hline PREDNISONE & $1.44 \pm 0.30^{b}$ & $1.25-1.63$ & & $1.56 \pm 0.20^{b}$ & $1.35-1.77$ & \\
\hline
\end{tabular}

$X \pm$ SD: Mean and Standard Deviation; $\varphi$ : Kruskal-Wallis test $(p<0.05)$. a: Dunn-Bonferroni test $(p<0.05$ with reference to the control group); b: Dunn-Bonferroni test ( $p<0.05$ with reference to the salbutamol group)

Table III - Osteoblast count according to treatment groups at days five and seven

\begin{tabular}{|ccccccc|}
\hline GROUP & \multicolumn{3}{c}{ DAY FIVE } & \multicolumn{3}{c|}{ DAY SEVEN } \\
\hline CONTROL & $\mathbf{X} \pm$ SD & IC 95\% & $\mathbf{p} \varphi$ & $\mathbf{X} \pm$ SD & IC 95\% & $\mathbf{p}^{\varphi}$ \\
\hline SALBUTAMOL & $22.0 \pm 4.38^{\mathrm{b}}$ & $17.40-26-60$ & 0.003 & $32.17 \pm 2.32^{\mathrm{b}}$ & $29.74-43.60$ & $<0.001$ \\
\hline MONTELUKAST & $21.50 \pm 4.09^{\mathrm{a}}$ & $25.21-33.79$ & & $40.33 \pm 1.97^{\mathrm{a}}$ & $38.27-42.40$ & \\
\hline PREDNISONE & $21.17 \pm 3.1^{\mathrm{b}}$ & $18.36-25.31$ & & $31.50 \pm 3.62^{\mathrm{b}}$ & $27.70-35.30$ & \\
\hline
\end{tabular}

$X \pm$ SD: Mean and Standard Deviation; $\varphi$ : Kruskal-Wallis test $(p<0.05)$. a: Dunn-Bonferroni test $(p<0.05$ with reference to the control group); b: Dunn-Bonferroni test ( $p<0.05$ with reference to the salbutamol group)

Table IV - Osteocyte count according to treatment groups at days five and seven

\begin{tabular}{|c|c|c|c|c|c|c|}
\hline \multirow{2}{*}{ GROUP } & \multicolumn{3}{|c|}{ DAY FIVE } & \multicolumn{3}{|c|}{ DAY SEVEN } \\
\hline & $X \pm S D$ & IC 95\% & $\mathbf{p}^{\varphi}$ & $X \pm S D$ & IC 95\% & $\mathbf{p} \varphi$ \\
\hline CONTROL & $15.83 \pm 2.79^{b}$ & $12.91-18.76$ & 0.001 & $21.17 \pm 3.06^{b}$ & $17.95-24.38$ & $<0.001$ \\
\hline SALBUTAMOL & $21.50 \pm 2.88^{a}$ & $18.48-24.52$ & & $30.50 \pm 2.59^{a}$ & $27.78-33.22$ & \\
\hline MONTELUKAST & $16.33 \pm 1.75^{b}$ & $14.50-18.17$ & & $21.83 \pm 2.48^{b}$ & $19.23-24.44$ & \\
\hline PREDNISONE & $15.17 \pm 2.79^{b}$ & $12.24-18.09$ & & $20.17 \pm 3.19^{b}$ & $16.82-23.51$ & \\
\hline
\end{tabular}

$X \pm$ SD: Mean and Standard Deviation; $\varphi$ : Kruskal-Wallis test $(p<0.05)$. a: Dunn-Bonferroni test ( $p<0.05$ with reference to the control group); b: Dunn-Bonferroni test ( $p<0.05$ with reference to the salbutamol group) 


\section{Histopathological analysis}

In the evaluation of the osteoblast and osteocyte count in all study groups, a significant difference was found at five and seven days ( $\mathrm{p}$ $<0.05$ ) (Figures 2 and 3).

In the post-hoc analysis, similarity was found in the cell count of osteoblasts and osteocytes among the control, montelukast, and prednisone groups. These groups were different from the salbutamol group ( $p<0.05$ ) (Tables III and IV).
In the histopathological analysis, it was evident that at five and seven days, the salbutamol group presented a large formation of bone trabeculae with a greater presence of osteoblasts and osteocytes (Figures 2B and 3B, respectively) compared to the other groups.

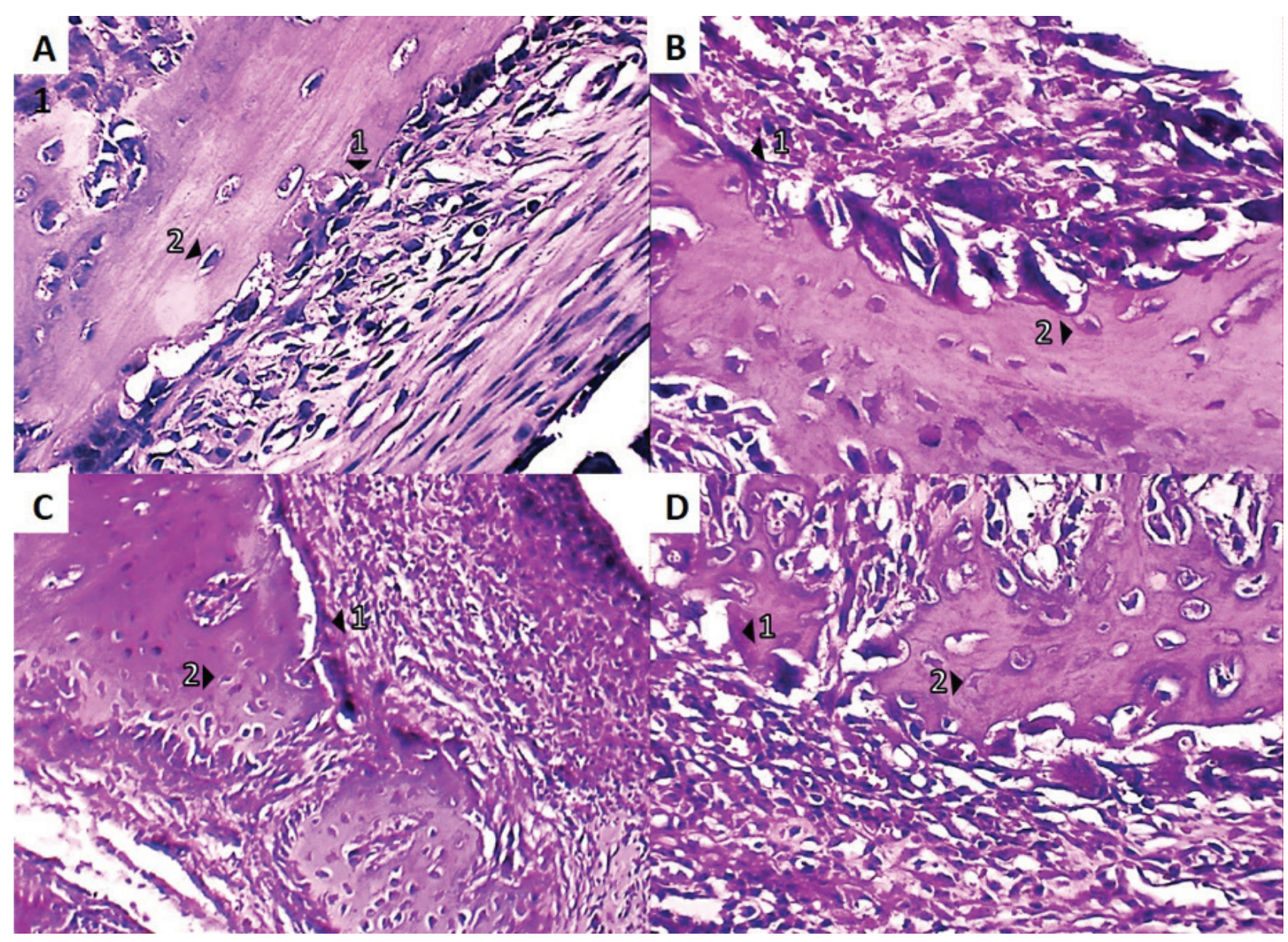

Figure 2 - Microphotographs of representative areas of each experimental group are observed at magnifications of 400x and stained with $\mathrm{H}$-E; with the presence of 1: osteoblasts, 2: osteocytes. 2A. Control Group at day 5. Few osteoblasts are seen around the initial formations of bone trabeculae. 2B. Salbutamol Group at day 5. Important trabecular formation is observed with osteocytes and osteoblasts. 2C. Montelukast Group at day 5. Some osteoblasts are seen around the forming trabeculae. 2D. Prednisone group at day 5. Few osteocytes are seen in the forming trabeculae. 


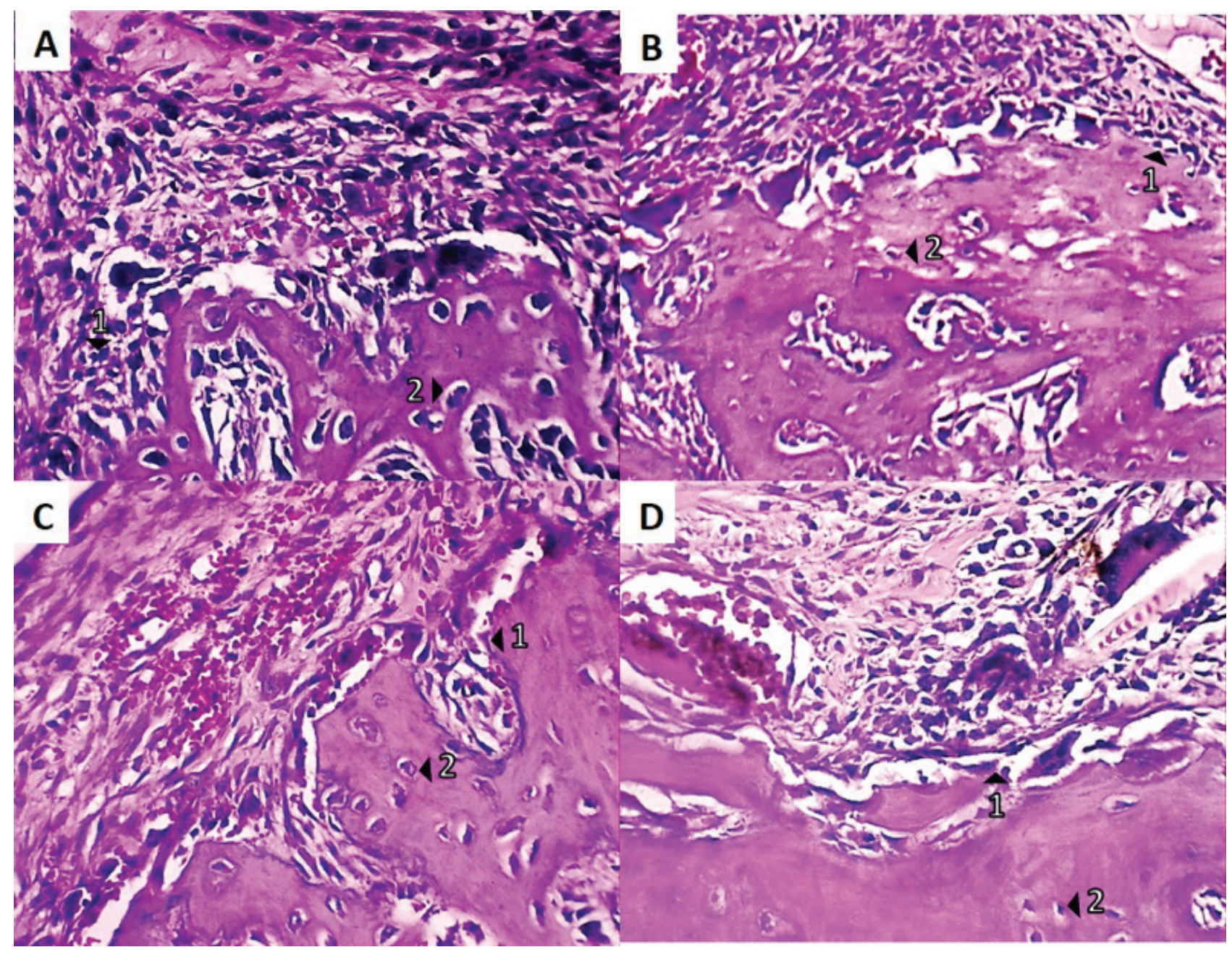

Figure 3 - Microphotographs of representative areas of each experimental group are observed at magnifications of 400x and stained with $\mathrm{H}$-E; with the presence of 1: osteoblasts, 2: osteocytes. 3A. Control Group at day 7. Osteoblasts are seen around bone trabeculae. 3B. Grupo Salbutamol at day 7. High trabecular density is observed with osteocytes and osteoblasts. 3C. Montelukast Group at day 7. Osteoblasts are seen around the bone trabeculae. 3D. Prednisone group at day 7. Few osteocytes are seen in the trabeculae.

\section{DISCUSSION}

In the present investigation, it was found that the administration of salbutamol (beta- 2 agonist) produced a positive effect on OTM by presenting a greater variation in the interincisal distance and a higher cell count compared to the other groups. These findings were similar to those of Kondo et al. [20], who reported that the administration of isoproterenol (non-selective beta agonist) significantly increased the magnitude of the OTM in mice, on the third and fifth day of treatment (increasing the number of osteoclasts). Furthermore, they found that the administration of propanolol (non-selective beta antagonist) suppressed OTM from the third day of treatment. It is suggested that adrenergic signaling influences OTM significantly.

The findings of the present investigation are similar to those reported by Yao et al. [10] and Liang et al. [9]., who found that the administration of isoproterenol in osteocyte cell cultures increased the ratio between the activating nuclear factor kappa- $\beta$ receptor ligand (RANKL) and osteoprotegerin (OPG), 
which causes osteoclastogenesis. Liang et al. [9], demonstrated that a beta 2 agonist (clenbuterol) promoted the growth of osteocytic cells, the formation of osteoclasts and increased the expression of RANKL, accelerating bone turnover and reabsorption.

The findings of the study correlate with those reported by Uchibori et al. [21] and De Oliveira et al. [22], who found that butoxamine (selective beta-2 antagonist) inhibited OTM in rats, due to the inhibition of osteoclasts and RANKL in the pressure zone and the decrease in osteocytes in the tension zone. De Oliveira et al. [19] found that propranolol inhibited bone remodeling and OTM en rats due to the reduction of interleukin-1 $\beta$ (IL-1 $\beta$ ) and interleukin-6 (IL6 ) and a lower expression of the intercellular adhesion molecule-1 (ICAM-1) and RANKL.

In the present investigation, we did not find a significant effect of the administration of montelukast on OTM. These results disagree with that reported by Ju-Hee Kang et al. [23] who found that a benzoxazole derivative (5-lipoxygenase inhibitor) significantly reduced RANKL-induced osteoclast formation and inhibited nuclear transcription factor kappa- $\beta$ (NF-KB), reducing the induction of osteoclasts in cell cultures. Moura et al. [24] found that zileuton (5-lipoxygenase inhibitor) and montelukast (leukotriene receptor blocker), reduced osteoclast differentiation and the production of tumor necrosis factor-alpha (TNFa), decreasing bone resorption and OTM in mice. These significant differences in the reduction of the OTM in Moura's study were possibly due to the $350 \mathrm{~g}$ force used, compared to the $35 \mathrm{~g}$ of the present investigation.

No significant effect of prednisone administration on OTM was found in this investigation. This differs from that reported by Bergström et al. [25] who found that prednisolone $(11 \mathrm{mg} / \mathrm{kg} /$ day $)$ decreased the increase in trabecular bone density and the expression of genes associated with osteoblasts, and also decreased the proportion of osteocytes/ osteoblasts in mice. These significant effects from Bergström's study were possibly due to high doses of prednisolone (generating a more intense effect with a greater probability of inhibiting osteoblast differentiation). Yang et al. [26] showed that high levels of glucocorticoids in mice are an important factor in accelerated bone resorption due to apoptosis of osteocytes/ osteoblasts, increasing osteoclastic activity and RANKL expression. Sato et al. [6] evaluated the effect of the administration of prednisolone $(1.4 \mathrm{mg} / \mathrm{kg} /$ day for 28 days) in mice, on the apoptosis of osteocytes and osteoblastic cells, demonstrating that it presents a proapoptotic effect in osteoblastic cells, reducing bone mineral density. Piemontese et al. [27] found that the administration of prednisolone $(2.1 \mathrm{mg}$ / $\mathrm{kg}$ /day for 28 days) in mice promoted osteocyte autophagy, reduced the number of osteoblasts and increased the number of osteoclasts in the femur of adult mice.

Previously cited studies report that prolonged exposure to glucocorticoids can promote and accelerate bone resorption, which can promote greater speed in turnover processes, increasing the speed of OTM. In the present investigation, no significant difference was found in the magnitude of the OTM between the group that received prednisone compared to the control group, most likely because prednisone was administered in short 5-day therapy, unlike the studies previously cited in which used 28day prolonged therapies. Due to its mechanism of action, the gene changes produced by glucocorticoids are more evident with prolonged therapies [28].

The present investigation evaluated orthodontic tooth movement focusing on the formative part of the bone remodeling process, which is why the osteoblast count (bone-forming cells) and their mature form (osteocytes) were mainly considered. Murshid [29] shows 
that osteocytes play an important role as mechanosensitive receptors in orthodontic tooth movement, which direct bone apposition on the tension side and can also modulate bone resorption on the compression side. On the other hand, Lerner [30] highlights the importance of osteoblasts, not only in the production of the extracellular matrix and mineralization of bone, but also has endocrine activity (secretion of osteocalcin) regulating the differentiation and activity of osteoclasts. For the reasons stated, the present research considered osteoblasts as the most determining cells for orthodontic tooth movement.

The present study has the strength of including three frequently prescribed antiasthmatic medications. It has as limitations not having included different doses of the drugs and a longer period of administration. Biomarkers could be used in future studies to assess bone resorption and apposition processes.

It is recommended for future studies to consider the administration of different doses and duration of treatment with salbutamol, montelukast and prednisone to evaluate its effect on OTM.

\section{CONCLUSION}

The administration of salbutamol increased the magnitude of orthodontic tooth movement. However, the administration of montelukast and prednisone had no effects on the magnitude of orthodontic tooth movement in a preclinical model in rats.

\section{Funding source}

This study was subsidized by the National University of San Marcos, 130501031 (RAIS).

\section{Acknowledgment}

Our sincere gratitude to the National University of San Marcos for providing us with financial support to carry out this research work.

\section{Conflicts of interest}

There is no type of financial and nonfinancial conflicts of interest from the authors.

\section{REFERENCES}

1. Alqahtani H. Medically compromised patients in orthodontic practice: Review of evidence and recommendations. Int Orthod. 2019 Dec;17(4):77688. https://doi.org/10.1016/j.ortho.2019.08.015

2. Inagaki Y, Akahane M, Shimizu T, Inoue K, Egawa T, Kira T, et al. Modifying oxygen tension affects bone marrow stromal cell osteogenesis for regenerative medicine. World J Stem Cells. 2017;9(7):98-106. https://dx.doi. org/10.4252/wjsc.v9.17.98

3. Chumpitaz-Cerrate V,Bellido-Meza JA, Chavez-Rimache L, RodriguezVargas C. Impact of inhaler use on dental caries in asthma pediatrics patients: A case-control study. Arch Argent Pediatr. 2020 Feb;118(1):38-46. http://dx.doi.org/10.5546/aap.2020.eng.38

4. Bartzela T, Turp JC, Motschall E, Maltha JC. Medication effects on the rate of orthodontic tooth movement: a systematic literature review. Am J Orthod Dentofacial Orthop. 2009 Jan;135(1):16-26. https://doi.org/10.1016/j. ajod0.2008.08.016

5. Asaad H, Al-Sabbagh R, Al-Tabba D, Kujan O. Effect of the leukotriene receptor antagonist montelukast on orthodontic tooth movement. J Oral Sci. 2017;59(2):297-302. https://doi.org/10.2334/josnusd.16-0482

6. Sato AY, Tu X, McAndrews KA, Plotkin LI, Bellido T. Prevention of glucocorticoid induced-apoptosis of osteoblasts and osteocytes by protecting against endoplasmic reticulum (ER) stress in vitro and in vivo in female mice. Bone. 2015 Apr;73:60-8. https://doi.org/10.1016/j. bone.2014.12.012

7. Machado CC, Nojima Mda C, Rodrigues e Silva PM, Mandarim-de-Lacerda CA. Histomorphometric study of the periodontal ligament in the initial period of orthodontic movement in Wistar rats with induced allergic asthma. Am J Orthod Dentofacial Orthop. 2012 Sep;142(3):333-8. https://doi.org/10.1016/j. ajodo.2012.04.011

8. Chibebe PC, Starobinas N, Pallos D. Juveniles versus adults: differences in PGE2 levels in the gingival crevicular fluid during orthodontic tooth movement. Braz Oral Res. 2010 Mar;24(1):108-13. http://dx.doi.org/10.1590/ S1806-83242010000100018

9. Liang $\mathrm{H}$, Zeng $\mathrm{Y}$, Feng $\mathrm{Y}$, Wu H, Gong $\mathrm{P}$, Yao Q. Selective beta2-adrenoreceptor signaling regulates osteoclastogenesis via modulating RANKL production and neuropeptides expression in osteocytic MLO-Y4 cells. J Cell Biochem. 2018;1-10. https://doi.org/10.1002/jcb.27998

10. Yao Q, Liang $\mathrm{H}$, Huang B, Xiang L, Wang T, Xiong Y, et al. Beta-adrenergic signaling affect osteoclastogenesis via osteocytic MLO-Y4 cells' RANKL production. Biochem Bioph Res Co. 2017;488(4):634-40. https://doi. org/10.1016/j.bbrc.2016.11.011

11. Cottrell J, O'Connor JP.Effect of Non-Steroidal Anti-Inflammatory Drugs on Bone Healing. Pharmaceuticals (Basel, Switzerland). 2010;3(5):1668-93. https://doi.org/10.3390/ph3051668

12. Nie Z, Chen S, Peng H. Glucocorticoid induces osteonecrosis of the femoral head in rats through GSK3 $\beta$-mediated osteoblast apoptosis. Biochem Bioph Res Co. 2019 Apr 9;511(3):693-699. https://doi.org/10.1016/j.bbrc.2019.02.118 
13. Garcia-Martinez O,Diaz-Rodriguez L, Rodriguez-Perez L, De Luna-Bertos E, Reyes Botella C, Ruiz CC. Effect of acetaminophen, ibuprofen and methylprednisolone on different parameters of human osteoblast-like cells. Arch Oral Biol. 2011 Apr;56(4):317-23. https://doi.org/10.1016/j. archoralbio.2010.10.018

14. Krishnan V, Vijayaraghavan N, Manoharan M, Raj J, Davidovitch Z. The Effects of Drug Intake by Patients on Orthodontic Tooth Movement. Seminars in Orthodontics. 2012;18(4):278-85. https://doi.org/10.1053/j.sodo.2012.06.006

15. ARRIVE guidelines | NC3Rs [Internet]. [cited 2020 May 8]. Available from: https://www.nc3rs.org.uk/arrive-guidelines.

16. National Research Council (US) Committee for the Update of the Guide for the Care and Use of Laboratory Animals. Guide for the Care and Use of Laboratory Animals [Internet]. 8th ed. Washington (DC): National Academies Press (US); 2011 [cited 2020 May 8]. (The National Academies Collection: Reports funded by National Institutes of Health). Available from: http://www. ncbi.nlm.nih.gov/books/NBK54050/

17. Novaes A, Desiderá A, Nascimento G and Leite-Panissi C. Effects of Sodium Diclofenac on the Distribution of Fos Protein in Central Amygdala and Lateral Hypothalamus during Experimental Tooth Movement in Rats. World J Neurosci. 2014;4(1):183-189. doi: 10.4236/wjns.2014.42021.

18. Gonçalves CF, Desiderá AC, do Nascimento GC, Issa JP, Leite-Panissi CR. Experimental tooth movement and photobiomodulation on bone remodeling in rats. Lasers Med Sci. 2016;31(9):1883-1890. doi:10.1007/s10103-016-2064-y

19. Magdalena CM., Navarro VP,Park DM, Stuani MB and Rocha MJ. c-Fos Expression in Rat Brain Nuclei Following Incisor Tooth Movement. J Dent Res. 2004;83(1):50-54. http://dx.doi.org/10.1177/154405910408300110

20. Kondo M, Kondo H, Miyazawa K, Goto S, Togari A. Experimental tooth movement-induced osteoclast activation is regulated by sympathetic signaling. Bone. 2013 Jan;52(1):39-47.https://doi.org/10.1016/j. bone.2012.09.007

21. Uchibori S, Sekiya T, Sato T, Hayashi K, Takeguchi A, Muramatsu R, et al. Suppression of tooth movement-induced sclerostin expression using $\beta$-adrenergic receptor blockers. Oral Diseases. 2020;26(3):621-9. https:// doi.org/10.1111/odi.13280
22. De Oliveira EL, Freitas FF, de Macedo CG, Clemente-Napimoga JT, Silva MBF, Manhães-Jr LRC, et al. Low dose propranolol decreases orthodontic movement. Arch Oral Biol. 2014;59(10):1094-100. https://doi.org/10.1016/j. archoralbio.2014.06.006

23. Kang JH, Ting Z, Moon MR, Sim JS, Lee JM, Doh KE, et al. 5-Lipoxygenase inhibitors suppress RANKL-induced osteoclast formation via NFATc1 expression. Bioorg Med Chem. 2015 Nov 1;23(21):7069-78. https://doi. org/10.1016/j.bmc.2015.09.025

24. Moura AP, Taddei SR, Queiroz-Junior CM, Madeira MF, Rodrigues LF, Garlet $\mathrm{GP}$, et al. The relevance of leukotrienes for bone resorption induced by mechanical loading. Bone. 2014 Dec;69:133-8. https://doi.org/101016/j. bone.2014.09.019

25. Bergström I, Isaksson H, Koskela A, Tuukkanen J, Ohlsson C, Andersson G, et al. Prednisolone treatment reduces the osteogenic effects of loading in mice. Bone.2018;112:10-8.https://doi.org/10.1016/j.bone.2018.04.002

26. Yang J, Li J, Cui X, Li W, Xue Y, Shang P, et al. Blocking glucocorticoid signaling in osteoblasts and osteocytes prevents mechanical unloading-induced cortical bone loss. Bone. 2020 Jan;130:115108. https://doi.org/10.1016/j. bone.2019.115108

27. Piemontese M, Onal M, Xiong J, Wang Y, Almeida M, Thostenson JD, et al. Suppression of autophagy in osteocytes does not modify the adverse effects of glucocorticoids on cortical bone. Bone. 2015;75:18-26. https://doi. org/10.1016/j.bone.2015.02.005

28. Wood CL, Soucek 0, Wong SC, Zaman F, Farquharson C, Savendahl L, et al. Animal models to explore the effects of glucocorticoids on skeletal growth and structure. JEndocrinol. 2018 Jan;236(1):R69-r91. https://doi.org/10.1530/ JOE-17-0361

29. Murshid S.A. The role of osteocytes during experimental orthodontic tooth movement: A review. Archives of Oral Biology. 2017; 73: 25-33. http://dx.doi. org/10.1016/j.archoralbio.2016.09.001

30. Lerner U.H. Osteoblasts, Osteoclasts, and Osteocytes: Unveiling Their Intimate-Associated Responses to Applied Orthodontic Forces. Seminars in Orthodontics. 2012; 18(4):237-248. http://dx.doi.org/10.1053/j. sodo.2012.06.002

Victor Manuel Chumpitaz-Cerrate (Corresponding address) 